logos_i_ethos_2016_2_(42), s. 137-156

DOI: http://dx.doi.org/10.15633/lie.1918

Andrzej Kobyliński

Uniwersytet Kardynała Stefana Wyszyńskiego w Warszawie

\title{
Problem nowej moralności w komunizmie, faszyzmie i narodowym socjalizmie
}

2 czerwca 2016 roku niemiecki Bundestag przyjął uchwałę potępiającą rzeź Ormian, dokonaną w latach 1915-1917. Wymordowanie podczas pierwszej wojny światowej ok. 1,5 mln bezbronnych ludzi przez imperium osmańskie stanowi-

Andrzej Kobyliński - doktor habilitowany nauk humanistycznych w dyscyplinie filozofia, absolwent Papieskiego Uniwersytetu Gregoriańskiego w Rzymie. Pracownik Instytutu Filozofii Uniwersytetu Kardynała Stefana Wyszyńskiego w Warszawie. Kierownik Studiów Podyplomowych Bioetyki i Prawa Medycznego UKSW w Warszawie. ło początek niewiarygodnego barbarzyństwa XX wieku. W języku ormiańskim stosuje się wyrażenie „Mec Jeghern” (wielka zbrodnia, zagłada, wielkie nieszczęście) na określenie okrutnej czystki etnicznej, dokonanej przez Turków w stosunku do narodu ormiańskiego ${ }^{1}$. W wielu krajach świata, szczególnie w państwach totalitarnych, doprowadzono w ubiegłym stuleciu do fizycznej eksterminacji, tortur, prześladowań kilkuset milionów ludzi.

Parlament w Berlinie - podobnie jak uczyniły to wcześniej władze w Paryżu czy Moskwie - uznał rzeź Ormian za ludobójstwo. Niestety, Turcja nie zgadza się na stosowanie tej kategorii w odniesieniu do „Mec Jeghern”. Za każdym razem, gdy masakra czy holokaust Ormian są nazywane ludobójstwem, władze w Ankarze stanowczo protestują. Ze zdecydowanym sprzeciwem Turcji spotkała się także ostatnia uchwała Bundestagu - Ankara wezwała na konsultacje swojego ambasadora w Niemczech, zaś prezydent Recep Tayyip Erdogan stwierdził, że decyzja 
niemieckiego parlamentu odbije się na wzajemnych relacjach między Berlinem i Ankarą.

Wieloletni spór o ocenę moralną ludobójstwa Ormian stanowi część wielkiego problemu europejskiego i światowego, który dotyczy analizy przyczyn i specyfiki wielu innych niewyobrażalnych zbrodni XX wieku. Szczególne formy barbarzyństwa i okrucieństwa były praktykowane przez trzy dwudziestowieczne systemy totalitarne: komunizm, faszyzm i narodowy socjalizm. Od wielu lat dramatyczne wydarzenia ubiegłego stulecia są przedmiotem szeroko zakrojonych badań historycznych, socjologicznych, politologicznych. Zrozumienie najgłębszych przyczyn stworzenia w ubiegłym stuleciu nowej moralności oraz interpretacja fenomenu zła i rzekomej konieczności zbrodni wymagają także pogłębionych analiz filozoficznych.

Jakie były korzenie ideowe i światopoglądowe tych zbrodniczych ideologii? W jaki sposób uzasadniano w państwach totalitarnych nową moralność, która usprawiedliwiała stosowanie przemocy i mordowanie niewinnych ludzi? Dlaczego wiele niewiarygodnych zbrodni XX wieku pozostaje w dużym stopniu wciąż nieopisanych? Jaka etyka jest możliwa po tragedii Auschwitz i Kołymy?

Głównym celem artykułu jest analiza specyfiki systemów totalitarnych według Alaina Besançona, Augusta Del Nocego i Rolfa Zimmermanna, a także ukazanie głównych cech nowej moralności, która obowiązywała w komunizmie, faszyzmie i narodowym socjalizmie. W dziełach tych trzech myślicieli, którzy walnie przyczynili się do głębszego uchwycenia natury systemów totalitarnych, jest zawarte wspólne przekonanie, że mit samozbawienia człowieka i projekt raju na ziemi stanowią najgłębszą przyczynę zła i zbrodni XX wieku.

\section{Zbrodniczy charakter komunizmu i nazizmu}

Jedną z najciekawszych diagnoz systemów totalitarnych wypracował w ostatnich latach francuski historyk, politolog i sowietolog Alain Besançon (1932-). Jego badania wyraźnie pokazują, że reżimy totalitarne doprowadziły świat w XX stuleciu do wielkiej destrukcji moralnej, 
społecznej i cywilizacyjnej. Najłagodniejszą formę miał niewątpliwe faszyzm, natomiast komunizm i narodowy socjalizm należy uznać za bardzo podobne do siebie barbarzyńskie systemy zniewolenia i przemocy, które są odpowiedzialne za zbrodnie ludobójstwa na niewyobrażalną skalę.

W odniesieniu do komunizmu i nazizmu Besançon stosuje określenie „bliźnięta dwujajowe” lub „bliźnięta heterozygotyczne”2. W sensie medycznym bliźnięta tego rodzaju przychodzą na świat w wyniku zapłodnienia dwóch odrębnych komórek jajowych przez dwa osobne plemniki. Od samego początku powstają więc dwa oddzielne i różne embriony. $\mathrm{W}$ sposób analogiczny narodziły się także w XX wieku dwa reżimy totalitarne: komunizm i narodowy socjalizm. Francuski sowietolog twierdzi, że te polityczne „bliźnięta dwujajowe”, nawet jeśli wobec siebie były wrogie, to posiadają wiele cech wspólnych i wyrastają z bardzo podobnej matrycy ideowej i światopoglądowej.

Za cel stawiają sobie społeczeństwo doskonałe, usuwając złą zasadę, która staje im na przeszkodzie. Uważają się za dobroczynne, ponieważ pragną, jedno - dobra całej ludzkości, drugie - dobra narodu niemieckiego, ideały, którym odpowiedzią były entuzjastyczne oddanie i heroiczne czyny. Najbardziej wszakże zbliża je przyznanie sobie prawa, a nawet obowiązku zabijania, co oba dokonały podobnymi sposobami na skalę nieznaną w historii ${ }^{3}$.

Komunizm i narodowy socjalizm należy uznać za dyktatury w równym stopniu zbrodnicze - bestialskie mordy na masową skalę stanowią

2 Jednym z polskich autorów określających komunizm i narodowy socjalizm jako dwa bliźniacze systemy totalitarne był Gustaw Herling-Grudziński. Jego książka Inny świat. Zapiski sowieckie, napisana w latach 1949-1950, opublikowana po raz pierwszy w przekładzie angielskim w 1951 roku w Londynie (pt. A world apart: the journal of a Gulag survivor), była jednym z pierwszych dokumentów literackich, pokazujących zbrodniczość systemu komunistycznego.

A. Besançon, Przekleństwo wieku: o komunizmie, narodowym socjalizmie i jedyności Zagłady, tłum. J. Guze, Warszawa 2000, s. 7. Warto dodać, że w tytule włoskiego wydania tej książki zostało użyte wyrażenie „stulecie zła” (il secolo del male) na określenie XX wieku, które niezwykle dobitnie oddaje skalę dramatu spowodowanego w świecie przez komunizm, faszyzm i narodowy socjalizm. Por. A. Besançon, Novecento. Il secolo del male. Nazismo, comunismo, Shoah, traduzione a cura di S. Congia, Roma 2000. 
podstawę ich funkcjonowania i należą do ich natury. Nowa moralność, okrucieństwo oraz zbrodniczość to elementy wspólne tych dwóch systemów totalitarnych. Warto podkreślić, że Besançon przejął wyrażenie „bliźnięta dwujajowe" na określenie podobieństwa między komunizmem i narodowym socjalizmem od Pierre’a Chaunu (1923-2009). Francuski historyk twierdził, że komunizm i narodowy socjalizm - jako dwa bliźniacze i zbrodnicze systemy totalitarne - nawet jeśli wywodzą się z różnych tradycji kulturowych i historycznych, mają wiele wspólnych elementów ideowych i światopoglądowych.

Marksizm-leninizm, ciągle odgrywający kluczową rolę w takich krajach, jak Chiny czy Korea Północna, nawiązuje do Heraklita, Demokryta, tradycji oświecenia czy Hegla, natomiast nazizm inspirował się tragedią grecką, Herderem, Novalisem, częścią twórczości Hegla i Nietzschego. Podobieństwo istniejące między komunizmem i narodowym socjalizmem jest widoczne przede wszystkim na poziomie uzasadniania rzekomej konieczności zbrodni. Besançon zauważa, że ideologia tych dwóch systemów totalitarnych koncentruje się na wizji stworzenia nowego świata, który ma w sobie pewne elementy religijne i mesjanistyczne. Utopia, raj na ziemi, zbawienie w wymiarze ziemskim - to główne cele rewolucji komunistycznej i nazistowskiej. Ideolodzy narodowego socjalizmu mówili o zbawieniu dla rasy niemieckiej, natomiast zwolennicy komunizmu wciąż roztaczają wizję raju na ziemi dla całej ludzkości. Żeby zbudować nowy świat, konieczna jest radykalna transformacja społeczeństwa, która łączy się z eksterminacją milionów niewinnych ofiar.

Komunizm i nazizm, aby uzasadnić swoją prawowitość, odwołują się do autorytetu nauki. Stawiają się w roli mentorów ludzkości, dążąc do stworzenia nowego człowieka. Obie ideologie chcą uchodzić za dobroczynne. Narodowy socjalizm pragnie dobra narodu niemieckiego i głosi, iż wyświadcza przysługę ludzkości, eliminując Żydów; leninowski komunizm od zarania stawia sobie za cel dobro całej ludzkości. Ten uniwersalny wymiar daje komunizmowi ogromną przewagę nad nazizmem, którego propagandowy zasięg jest ograniczony. Obie doktryny powołują się na „wzniosłe ideały”, mogące wyzwolić entuzjazm, bez- 
względne poświęcenie i heroizm. Narzucają równocześnie prawo i obowiązek zabijania ${ }^{4}$.

Twierdzenia Besançona dotyczące zbrodniczości komunizmu zostały potwierdzone w całej rozciągłości przez międzynarodowy zespół historyków, który opublikował w 1997 roku Czarna księgę komunizmu, dokumentując 100 milionów ofiar tej zbrodniczej ideologii w XX stuleciu. Zasadnicza teza tej książki, zgodna $\mathrm{z}$ ustaleniami francuskiego sowietologa, dotyczy uznania zbrodni za jeden z elementów właściwych systemowi komunistycznemu podczas całego okresu jego istnienia. Czarna księga komunizmu zestawia dwa totalitaryzmy - brunatny i czerwony jako formacje na równi zbrodnicze.

Chcąc utrwalić swoją władzę - twierdzi francuski historyk Stéphane Courtois reżimy komunistyczne wykroczyły poza jednostkowe zabójstwa i lokalne lub okolicznościowe masakry i uczyniły ze zbrodni masowej prawdziwy system rządów. To prawda, że z upływem czasu - po kilku latach w Europie Wschodniej i wielu dziesięcioleciach w ZSRR i w Chinach - terror utracił żywotność, reżimy ustabilizowały się w zarządzaniu codziennymi represjami, takimi jak cenzura wszystkich społecznych środków komunikacji, kontrola granic, wydalanie z kraju dysydentów. Ale „pamięć o terrorze" niezawodnie i skutecznie podtrzymywała nadal poczucie zagrożenia ${ }^{5}$.

Rzekoma konieczność zbrodni, dokonywanych przez komunistów i nazistów, była usprawiedliwiana tworzeniem nowego społeczeństwa, kształtowaniem nowej moralności, wizją swego rodzaju świeckiego zbawienia na ziemi. Można porównywać nazizm i komunizm jako dwie odmiany tego samego rodzaju - rodzaju ideologicznego. Łączy je ideologia radykalnej transformacji życia na ziemi i sposób uzasadniania rzekomej konieczności wymordowania milionów ludzi, aby stworzyć nowy ład na

4 A. Besançon, Świadek wieku. Wybór publicystyki z pierwszego i drugiego obiegu, t. 2, Warszawa 2006, s. 385-386.

5 S. Courtois, Zbrodnie komunizmu, [w:] Czarna księga komunizmu. Zbrodnie, terror, prześladowania, red. S. Courtois, N. Werth, J.-L. Panné, A. Paczkowski, K. Bartosek, J.-L. Margolin, tłum. K. Wakar, Warszawa 1999, s. 24. 
naszej planecie. Komunizm i narodowy socjalizm prowadzą do zafałszowania dobra i stworzenia nowej moralności przy wykorzystaniu starych pojęć: równości, sprawiedliwości, szczęścia czy dobra ludzkości.

Besançon podkreśla, że dobro moralne w narodowym socjalizmie polega na odbudowaniu porządku naturalnego, zniszczonego przez historię. Tego rodzaju przekonanie stanowiło jeden z centralnych elementów ideologii narodowosocjalistycznej ${ }^{6}$. Jednym z wielu przywódców Niemiec nazistowskich promujących ten sposób myślenia był dowódca SS i Gestapo Heinrich Himmler. Język jego przemówień miał charakter stricte etyczny. Himmler bardzo często mówił o heroizmie, poświęceniu, wierności, przezwyciężaniu siebie, pokonywaniu egoizmu, poczuciu obowiązku itp. Był przekonany, że trzeba ukazać wojsku, policji i całemu społeczeństwu najgłębsze uzasadnienia o charakterze moralnym, aby stworzyć idealną Trzecią Rzeszę, która będzie błogosławieństwem dla całej planety. Himmler ukazywał nową moralność jako drogę do skutecznego panowania nad ziemią oraz zapewnienia jej szczęścia i dobrobytu. Projekt narodowosocjalistyczny był prezentowany przez jego ideologów jako rzeczywistość światła i dobra, natomiast przeciwników traktowano jako insekty i szkodniki stojące po stronie ciemności i zła.

\section{Lew Trocki i Aleksander Zinowiew}

Podobną wizję nowej moralności zawiera także drugi bliźniaczy system totalitarny. W komunizmie funkcjonuje mit nowego człowieka, który oddaje się całkowicie dziełu rewolucji i z całą surowością usiłuje zniszczyć w sobie resztki dawnej moralności. Za klasyczny podręcznik etyki komunistycznej uznaje się książkę Lwa Trockiego z 1938 roku Ich moralność i nasza ${ }^{7}$. Książka prezentuje racje, dla których warto zburzyć resztki dawnej moralności, aby mógł narodzić się nowy człowiek. Dla stworzenia „raju na ziemi” komunizm wykorzystuje trzy wielkie kategorie myśli ludzkiej: sprawiedliwość, równość i wolność. Trocki nawiązuje

6 Por. A. Besançon, Przekleństwo wieku..., dz. cyt., s. 29-35.

7 L. Trocki, Ich moralność i nasza, tłum. P. Strębski, Warszawa 2004. 
w swojej etyce do koncepcji człowieka pierwotnie dobrego według Jakuba Rousseau - utraciliśmy pierwotną dobroć, ale komunizm ją odtworzy, przenosząc całe nasze istnienie na jeszcze wyższy poziom egzystencji. Trocki twierdził, że podstawowym poziomem nowej ludzkości, stworzonej przez komunizm, będzie Michał Anioł i Leonardo da Vinci. Dla osiągnięcia tak szczytnych i wielkich celów konieczne są makabryczne zbrodnie, krwawe rewolucje i niezliczone ofiary ${ }^{8}$.

Francuski sowietolog twierdzi, że wizja nowej moralności w etyce komunistycznej wyrządziła więcej zła niż projekt nowej moralności w etyce nazistowskiej. Dlaczego? Jego zdaniem etyka narodowego socjalizmu nie mogła stać się etyką uniwersalną całej ludzkości, ponieważ stosowała kategorię rasy, nadludzi, podludzi itp. Z tego powodu nie mogła dotyczyć ludzkości tout court i w konsekwencji wyrządziła mniej zła, bo zaraziła mniej umysłów niż etyka komunistyczna, która odwoływała się do idei internacjonalistycznych. Co więcej, nazizm określał dość precyzyjnie listę wrogów, dlatego w pewnym stopniu liczba ofiar była ograniczona. Natomiast komunizm tworzył ciągle nowe kategorie wrogów ludu, wrogów rewolucji - każdy mógł stać się insektem do eliminacji i dlatego liczba ofiar tego systemu jest tak niewiarygodnie wielka. Komunizm okazał się także bardziej perwersyjny niż nazizm, ponieważ wykorzystał ogólnoludzkie poczucie dobra i sprawiedliwości do tego, aby na całym świecie rozprzestrzeniać zło.

Besançon nawiązuje w swoich diagnozach komunizmu m.in. do opracowań Aleksandra Zinowiewa (1922-2006), który był - obok Aleksandra Sołżenicyna, Josifa Brodskiego czy Andrieja Sieniawskiego - jednym z najbardziej znanych dysydentów w Związku Radzieckim ${ }^{9}$. W wielu swoich publikacjach obnażał on absurdy komunistycznej utopii. Z powodu swoich poglądów został zmuszony do emigracji. Wydalenie z ojczyzny

8 Por. A. Besançon, Przekleństwo wieku..., dz. cyt., s. 36-46.

9 Por. A. Besançon, Przekleństwo wieku..., dz. cyt., s. 45. Najbardziej znanym opracowaniem Zinowiewa jest książka Przepastne wyżyny, która ukazała się w roku 1976 w Szwajcarii. To dzieło jest uważane w wielu środowiskach za jedną z najważniejszych książek XX wieku. Opracowanie Zinowiewa odsłania bezsens rzeczywistości społeczeństwa komunistycznego, ciągłą inwigilację, dehumanizację bytu ludzkiego, wszechobecne kłamstwo. 
potraktował jako wielką karę ${ }^{10}$. W latach 70. ubiegłego wieku Zinowiew stworzył termin homo sovieticus, który w Polsce został wprowadzony do domeny publicznej głównie za sprawą Józefa Tischnera. Określenie homo sovieticus charakteryzuje mentalność ludzi uformowanych w społeczeństwie radzieckim. Cechowała ich swoista dialektyka myślenia: byli jednocześnie zwolennikami reżimu i jego kontestatorami. Ta dwoistość sprawiała z kolei, że sami sobą pogardzali ${ }^{11}$.

Jednym z najważniejszych elementów diagnozy komunizmu i narodowego socjalizmu w wydaniu francuskiego sowietologa jest zwrócenie uwagi na nierówność pamięci o zbrodniach dokonanych przez dwa systemy totalitarne. Podczas gdy zło nazizmu zostało dobrze udokumentowane i potępione, zbrodnie komunizmu są wciąż w dużym stopniu okryte zasłoną milczenia.

Nazizm jest lepiej znany od komunizmu, bowiem szafa z trupami została szeroko otwarta przez aliantów, a niektóre narody zachodnioeuropejskie doświadczyły go na własnej skórze. Często zwracałem się - pisze Alain Besançon - do studentów z pytaniem, czy wiedzą coś o sztucznie wywołanym głodzie na Ukrainie w $1933 \mathrm{r}$. Nigdy o tym nie słyszeli. Zbrodnia nazistowska była przeważnie fizyczna. Nie zarażała moralnie swoich ofiar i świadków i nie domagała się, by wstępowali w szeregi nazistowskie. Jest jawna i można ją ustalić. Komory gazowe stworzone, by zlikwidować, w sposób przemysłowy, konkretnie określoną część ludzkości, to wymierny fakt. Gułag czy Laogai pozostają dalekie, jakby we mgle, znamy je pośrednio może poza jednym wyjątkiem, Kambodżą, gdzie odkopuje się do dzisiaj zbiorowe mogiły ${ }^{12}$.

10 „A differenza di altri dissidenti, era stato costretto a emigrare all'estero. Era stata una scelta forzata che non aveva condiviso, tanto che in un'intervista aveva detto: «A differenza di altri, io non avrei mai lasciato l'Urss se mi fosse stata lasciata la scelta. L'emigrazione è stata una vera punizione»” (F. Panzeri, Torna l’utopia oscura del dissidente Zinov'ev, „Avvenire” 49 (2016) 1, s. 16.

11 Por. A. Zinowiew, Homo sovieticus, tłum. S. Deja, London 1984.

12 A. Besançon, Świadek wieku..., t. 2, dz. cyt., s. 385-388. Swego rodzaju otwarciem trumny Draculi była publikacja w 1997 roku we Francji opracowania Czarna księa komunizmu. Ukazanie się tej książki sprowokowało ożywioną dyskusję publiczną m.in. w takich krajach, jak Francja, Niemcy czy Włochy. Niestety, w innych krajach świata - także w Polsce oraz w pozostałych 
Warto podkreślić, że ,jednym z większych sukcesów reżimu sowieckiego było rozpowszechnianie i powolne narzucanie swojej własnej, ideologicznej klasyfikacji współczesnych ustrojów politycznych"13. W konsekwencji międzynarodowa pamięć historyczna traktuje niejednakowo zbrodnie komunistyczne i nazistowskie. Francuski sowietolog domaga się, aby przy ocenie zbrodni z przeszłości stosować takie same kryteria wobec wszystkich. Rozliczenie i potępienie komunizmu powinno być równie ważne, jak rozliczenie i potępienie narodowego socjalizmu, a nawet bardziej, ponieważ „nazizm w przeciwieństwie do komunizmu nie był zjawiskiem światowym. Należy nieustannie uświadamiać siłę tego światowego, zabójczego wirusa. Zwłaszcza że wirus komunizmu może się jeszcze uaktywnić" ${ }^{14}$.

\section{Od sekularyzacji do faszyzmu}

Filozoficzną analizę komunizmu, faszyzmu i narodowego socjalizmu prowadził w ubiegłym stuleciu także włoski myśliciel Augusto Del Noce (1910-1989). Specyfika jego badań dotyczy połączenia problemu systemów totalitarnych $\mathrm{z}$ fenomenem sekularyzacji, której istotą jest powstanie w czasach nowożytnych immanentnej wizji świata i człowieka. Metoda badawcza tego filozofa, nazywanego przez wielu autorów włoskim Maritainem, polega na interpretacji transpolitycznej (interpretazione transpolitica) historii współczesnej. Istotą tej metody jest podkreślenie kluczowej roli, jaką odgrywa w historii przyczynowość o charakterze ideowym (causalità ideale). Przyjęcie tej przesłanki prowadzi do uchwycenia

państwach postkomunistycznych - książka została właściwie przemilczana. Francuzi, Niemcy i Włosi prowadzili poważny spór historyczny i filozoficzny dotyczący podstawowego pytania, czy można zrównywać dwa systemy totalitarne - brunatny i czerwony - i czy zbrodnie należą do istoty komunizmu? Wielu przedstawicieli życia publicznego nad Sekwaną, Tybrem czy Renem, broniących ideologii komunistycznej, stwierdzało w debacie publicznej, że nie można wyobrazić sobie narodowego socjalizmu bez komór gazowych, natomiast może istnieć komunizm bez gułagów.

13 A. Besançon, Świadek wieku..., t. 2, dz. cyt., s. 385-391.

14 A. Besançon, Świadek wieku. Wybór publicystyki z pierwszego i drugiego obiegu, t. 1, Warszawa 2006, s. 501. 
wzajemnej relacji o charakterze paralelnym między historią filozoficzną i historią polityczną, między filozofią i polityką.

„Del Noce przyznaje interpretacji transpolitycznej - twierdzi Vittorio Possenti - pierwszeństwo o charakterze wyjaśniającym nad innymi modelami interpretacyjnymi, które są nieadekwatne, aby zrozumieć historię współczesną, ponieważ są niezdolne do tego, aby zmierzyć się z marksizmem i faszyzmem na fundamencie autentycznej krytyki filozoficznej"15. W konsekwencji Del Noce odrzuca trzy, wypracowane wcześniej przez innych autorów, tradycyjne teorie dotyczące specyfiki systemu faszystowskiego. Po pierwsze, nie zgadza się z koncepcją Benedetta Crocego, który twierdzi, że faszyzm stanowi formę choroby moralnej i wyłom w rozwoju historii włoskiej i europejskiej. Po drugie, Del Noce kwestionuje stanowisko ideologii komunistycznej, która postrzega faszyzm jako reakcję antyproletariacką dominującej klasy burżuazyjnej (rolnictwo i wielki przemysł) przeciw zbyt głębokim zmianom społecznym. Po trzecie, włoski Maritain neguje także koncepcję radykalno-akcjonistyczną (radical-azionista), która odczytuje faszyzm jako kolejną odsłonę dawnych problemów historycznych, obecnych od wieków w społeczeństwie włoskim ${ }^{16}$.

Del Noce skupia się na tym, żeby poddać krytyce faszyzm oraz pozostałe systemy totalitarne nie tyle jako zbrodnię, ile jako błąd o charakterze intelektualnym i filozoficznym. Istotą błędu faszyzmu i antyfaszyzmu jest immanentyzm, negacja wymiaru nadnaturalnego oraz promocja ateistycznej wizji świata i człowieka. „Istnieje doskonały paralelizm - twierdzi Del Noce - między rozwojem włoskiej kultury immanentystycznej (cultura immanentistica) a procesem rozbicia Włoch, który rozpoczął się w sposób widzialny wraz z faszyzmem i ma swoją kontynuację w antyfaszyzmie. Ten proces musi trwać dalej, ponieważ antyfaszyzm zależy od tej samej kultury, z której wyrasta faszyzm, bądź z ostatniej formy jej rozwoju"17.

15 V. Possenti, Profili del Novecento, Torino 2007, s. 51.

16 Por. V. Possenti, Profili del Novecento, dz. cyt., s. 51.

17 A. Del Noce, Il suicidio della rivoluzione, Santarcangelo di Romagna 1978, s. 33. 
Jak narodziła się kultura immanentystyczna w kraju nad Tybrem oraz w całym świecie zachodnim? Gdzie szukać jej początków i „ojców założycieli”? Del Noce poddaje analizie filozoficznej główne idee nowożytności. Przeprowadzone badania doprowadzają go do wniosku, że źródeł kultury zamkniętej na transcendencję należy szukać w niektórych interpretacjach dzieła Kartezjusza ${ }^{18}$. Del Noce twierdzi, że w twórczości autora Rozprawy o metodzie są obecne dwa paradygmaty myślowe, z których wypłynęły dwa przeciwstawne nurty myśli ludzkiej i w konsekwencji ukształtowały się dwa przeciwstawne modele nowożytności ${ }^{19}$.

Pierwszy model - dzięki takim myślicielom, jak Blaise Pascal, Nicolas Malebranche i Giambattista Vico - czerpie swą inspirację z Kartezjusza i znajduje swoje dopełnienie w twórczości Antonia Rosminiego. W tym nurcie myśli nowożytnej nie występuje zamknięcie na transcendencję, wprost przeciwnie - nowożytność zachowuje otwartość na wymiar religijny i nie ma tutaj konfliktu między głównymi ideami świata nowożytnego a religijną wizją rzeczywistości. Jednym z najważniejszych elementów tego paradygmatu myślowego jest akceptacja grzechu pierworodnego, która oznacza świadomość stałej obecności zła w świecie. Owszem, należy dążyć do ograniczania różnych form zła, ale ludzkość nie jest w stanie doprowadzić do całkowitego usunięcia jego korzeni. Oznacza to w praktyce, że nie można stworzyć nowego człowieka i raju na ziemi. Włoski Maritain zakwestionował w ten sposób dominującą wizję interpretowania filozofii nowożytnej jako procesu jednorodnego, który prowadzi nieuchronnie od racjonalizmu Kartezjusza do absolutnej immanencji i ateizmu.

Do narodzin kultury immanentystycznej i ateizmu prowadzi druga linia rozwoju myśli nowożytnej, która - podobnie jak pierwsza - wyrasta z dzieła Kartezjusza, jest następnie rozwijana przez takich autorów, jak Baruch Spinoza czy Georg W. F. Hegel i znajduje swoje dopełnienie w filozofii Karola Marksa. W tym modelu nowożytności zostaje zanegowana

18 Por. A. Kobyliński, Chrześcijaństwo i nowożytność, „Collectanea Theologica” 74 (2004) 1, s. $138-140$.

19 Por. A. Del Noce, L'epoca della secolarizzazione, Torino 1970; A. Del Noce, Secolarizzazione e crisi della modernità, Napoli 1989. 
transcendentna wizja świata i człowieka. Ważnym elementem tego paradygmatu myślowego jest odrzucenie grzechu pierworodnego i tradycyjnej kategorii religijnej status naturae lapsae. W konsekwencji kategoria tzw. natury upadłej po grzechu pierworodnym została zastąpiona przez ideę pierwotnej doskonałości bytu ludzkiego. W tym ujęciu zostaje zanegowana strukturalna skończoność ludzkiej egzystencji, a przyczyny zła w historii mają charakter jedynie społeczno-kulturowy. W ten sposób otwiera się możliwość stworzenia doskonałego systemu politycznego, raju na ziemi oraz zbawienia o charakterze doczesnym i immanentnym, ponieważ tylko i wyłącznie w historii człowiek odnajduje sens swojej egzystencji i możliwość zbawienia.

Del Noce twierdzi, że spójną wizję tego rodzaju modelu nowożytności prezentuje filozofia marksistowska. W myśli Marksa mamy do czynienia z radykalną krytyką etyki chrześcijańskiej oraz z utopizmem i makiawelizmem. Marks zanegował tradycyjne kategorie filozoficzne natury ludzkiej, obowiązku, sumienia, prawa moralnego itp. W ten sposób zostały otwarte wrota, aby na drodze rewolucji doprowadzić do narodzin nowego człowieka i nowej moralności. Dlatego w faszyzmie - podobnie jak w komunizmie i narodowym socjalizmie - mamy do czynienia z pochwałą wojny, przemocy i zdobywania siłą nowych terytoriów ${ }^{20}$. Marks podporządkował etykę polityce i promował myślenie mesjanistyczne w wersji świeckiej. Do tej wersji świeckiego mesjanizmu i projektu zbudowania raju na ziemi odwołały się systemy totalitarne XX wieku, które dążyły do stworzenia nowego człowieka i kształtowały kulturę immanetystyczną.

\section{Benito Mussolini i Giovanni Gentile}

Del Noce odrzuca powszechne przekonanie, że faszyzm był ruchem reakcyjnym, tradycjonalistycznym i nacjonalistycznym. Niestety, w świadomości zbiorowej wielu społeczeństw wciąż funkcjonuje taki zafałszowany obraz systemu faszystowskiego jako ideologii o charakterze prawicowym. 
Włoski Maritain wykazuje w swoich opracowaniach, że stanowisko głównych założycieli ruchu faszystowskiego, Benita Mussoliniego (1883-1945) i Giovanniego Gentilego (1875-1944), jest antytetyczne wobec jakiejkolwiek formy politycznej o charakterze reakcyjnym, tradycjonalistycznym czy nacjonalistycznym. Twórców faszyzmu we Włoszech, szczególnie Mussoliniego, należy uznać za typowych przedstawicieli myśli marksistowskiej, socjalistycznej czy lewicowej ${ }^{21}$.

Del Noce interpretuje włoski faszyzm w ścisłej relacji z marksizmem. $\mathrm{W}$ ten sposób idzie pod prąd, kwestionując wiele dominujących opinii o charakterze filozoficznym, historycznym i socjologicznym. Diagnozy tego autora nawiązują do stanowiska niemieckiego myśliciela Ernsta Noltego, który twierdził, że każdy ruch totalitarny jest oporem przeciw transcendencji, rozumianej jako transcendencja historyczna, a nie metafizyczna $^{22}$. Del Noce stawia sobie za cel zburzenie dominującej interpretacji faszyzmu jako ruchu jednostkowego, sprzeciwiającego się całej historii nowożytnej począwszy od rewolucji francuskiej. Włoski Maritain wykazuje ciągłość między heglizmem, marksizmem i faszyzmem jako trzema momentami tego samego procesu sekularyzacji.

W badaniach Del Nocego ważną rolę odgrywa analiza pojęcia rewolucji, która stanowi podstawową kategorię marksizmu. Faszystowskie rozumienie rewolucji, inspirowane we Włoszech niemiecką filozofią ducha, dotyczy nie tyle poziomu społecznego i klasowego, ile wymiaru osobistego podmiotu. Spotkanie poglądów Mussoliniego z teoriami Gentilego doprowadziło do przekształcenia pojęcia rewolucji z wymiaru eschatologicznego - jak postulował marksizm, dążąc do stworzenia idealnego społeczeństwa komunistycznego - w kategorię solipsystyczną, określaną w kategoriach Gentilego jako aktualizm (attualismo).

Gentile wyłożył podstawy swojej koncepcji aktualizmu (attualis$m o$ ), będącej formą idealizmu absolutnego (idealismo assoluto) lub idealizmu aktualnego (idealismo attuale), w książce z roku 1913 Reforma

21 Por. E. Gentile, La via italiana al totalitarismo. Il partito e lo Stato nel regime fascista, Roma 2008.

22 Por. E. Nolte, Der Faschismus in seiner Epoche, München 1963. 
dialektyki Heglowskiej ${ }^{23}$ oraz w dziele z roku 1916 Ogólna teoria ducha jako aktu czystego ${ }^{24}$. Wraz z Benedetto Crocem (1866-1952) przyczynił się do odnowy idealizmu w kraju nad Tybrem i wypracowania specyficznej włoskiej formy myśli neoidealistycznej ${ }^{25}$. Gentile uzasadniał faszystowski ustrój społeczny jako „jedność myśli i działań całości narodu, widział w nim ideał państwa etycznego, nie dostrzegając przygodności natury ludzkiej i tworów człowieka" ${ }^{26}$. Podobnie jak u Hegla, w wizji Gentilego państwo jest rozumiane jako uosobienie jedności ducha, narodowej wspólnoty moralnej, kulturowej i językowej. W tej koncepcji duch stanowi podłoże ontyczne państwa, zawiera w sobie element Boski, a jednocześnie jest ucieleśnieniem jednostkowych świadomości $\mathrm{w}$ formie zbiorowej.

Del Noce jest jednym z niewielu autorów w kraju nad Tybrem, którzy poddają analizie nie tylko system faszystowski, ale także ideologię antyfaszyzmu. W domenie publicznej wielu społeczeństw wciąż dominuje przeświadczenie, że antyfaszyzm stanowi przezwyciężenie ideologii faszystowskiej. Del Noce zdecydowanie odrzuca takie przekonanie. Antyfaszyzm powinien być negacją faszyzmu, a nie jego odwróconą formą. W tradycji włoskiej antyfaszyzm nie był przezwyciężeniem faszyzmu, ponieważ została w nim zachowana dawna mentalność oraz postawy zdominowane przez kłamstwo i przemoc. We Włoszech proces rozpadu faszyzmu, funkcjonowania ruchu antyfaszystowskiego i narodzin demokracji po II wojnie światowej stanowi wciąż zagadnienie, które jest w dużym stopniu zasłonięte kurtyną milczenia. Dzieła włoskiego Maritaina są jedną z niewielu prób głębszej analizy filozoficznej tych bolesnych wydarzeń oraz całego okresu rządów faszystowskich w kraju nad Tybrem.

23 G. Gentile, Riforma della dialettica hegeliana, Messina 1913.
24 G. Gentile, Teoria generale dello spirito come atto puro, Pisa 1916.
25 Por. S. Battisti, Sfondo filosofico generale: l'Italia nel XX secolo, [w:] La filosofia cristiana nei secoli XIX e XX, t. 3: Correnti moderne del XX secolo, a cura di E. Coreth, W. M. Neidl, G. Pfligersdorffer, Roma 1995, s. 621-626.

26 W. Chudy, Gentile Giovanni, [w:] Powszechna encyklopedia filozofii, t. 3, red. A. Maryniarczyk, Lublin 2002, s. 750. 


\section{Wizja nowej ludzkości w narodowym socjalizmie}

Projekt stworzenia nowego człowieka i osiągnięcia zbawienia w wersji immanentnej zawiera także ideologia narodowego socjalizmu. Na ten element myśli nazistowskiej, łączący narodowy socjalizm z komunizmem, zwraca uwagę m.in. niemiecki filozof Rolf Zimmermann (1944-). Jego badania potwierdzają, że najgłębszym uzasadnieniem rzekomej konieczności zbrodni w obrębie komunizmu i nazizmu jest tzw. moralność zbawienia (Erlösungsmoral). Dotyczy ona możliwości osiągnięcia przez całą ludzkość raju na ziemi, ponieważ właśnie w historii człowiek odnajduje sens swojej egzystencji i możliwość zbawienia. W ten sposób ideologia komunistyczna i nazistowska zamykają eschaton w tym, co immanentne. Punktem wyjścia immanentyzacji eschatonu jest przypisanie zła historii i projektowanie go poza człowiekiem - w warunkach społecznych i zewnętrznych w stosunku do niego ${ }^{27}$.

Moralność zbawienia zakłada normatywnie ograniczoną koncepcję ludzkości. Roszczenie zawarte w tym projekcie, aby „ratować” całą ludzkość, ma ewidentnie charakter pseudouniwersalny, ponieważ zakłada dominację ideologii narodowosocjalistycznej i jest ukierunkowane na realizację określonej formy życiowej akceptowanej przez władze Trzeciej

27 „Die totalitären Formationen des Nationalsozialismus (NS) und Bolschewismus twierdzi Rolf Zimmermann - haben im 20. Jahrhundert zu epochalen Katastrophen geführt, die nicht nur wegen der damit verbundenen menschlichen Tragödien immer wieder Gegenstand von historischer Forschung und erinnernder Rückbesinnung sind, sondern auch wegen ihrer moralischen Relevanz der näheren Analyse bedürfen. Herkömmliche Vorverständnisse über Moral scheinen ins Wanken zu geraten, wenn man sich den Motiven der Protagonisten der Massenverbrechen des Holocaust oder des Holodomor zuwendet. Nicht weil es keine Maßstäbe gäbe, um diese Verbrechen zu verurteilen, sondern weil diese auf eine scheinbar paradoxe Diagnose verweisen. Je mehr nämlich das Selbstverständnis der leitenden oder beteiligten Akteure oder der Anhänger totalitärer Bewegungen in den Blick kommt, umso mehr wird die Einsicht bestärkt, dass die Vernichtung der Juden oder Kulaken unter normativen Vorzeichen geschieht, die sich zum Bild einer je anders gearteteten Moral verdichten. Daher halte ich es für angebracht, von Rassenmord oder Klassenmord aus Moral zu sprechen" (R. Zimmermann, Nationalsozialismus - Bolschewismus - Universalismus. Moralische Transformationen in der Geschichte als Problem der Ethik, [w:] Ideologie und Moral im Nationalsozialismus, bearb. W. Bialas, L. Fritze, Göttingen 2014, s. 369). 
Rzeszy ${ }^{28}$. Oddziały SS i inne zbrodnicze formacje nazistowskie były typowymi wspólnotami moralnej transformacji. Warto podkreślić, że szczególnie jednostki SS były nie tylko elitą w sensie militarnym, kierującą się w swoich działaniach motywami ideologicznymi i związanymi z walką rasową. Członkowie tych oddziałów uosabiali także paradygmat idealnej nazistowskiej socjalizacji (Nazi-Sozialisation) i moralnej transformacji, które powinny służyć całemu społeczeństwu jako model wychowawczy. Cnoty wierności, posłuszeństwa, czci i koleżeństwa były bezpośrednio odniesione do relacji z Adolfem Hitlerem. W ten sposób personifikacja cnót w figurze wodza znajdowała swój szczyt w przysiędze każdego esesmana, w której była ślubowana wierność Hitlerowi aż do śmierci ${ }^{29}$.

\section{Systemy totalitarne i idea radykalnej autonomii}

Analizy Zimmermanna charakteryzują się dość dużym podobieństwem do diagnoz zawartych w opracowaniach innego niemieckiego myśliciela Romana Guardiniego (1885-1968), który wskazuje w swych dziełach na motywy związane $\mathrm{z}$ ideą zbawienia i postacią zbawiciela $\mathrm{w}$ ideologii narodowosocjalistycznej. Zdaniem tego autora elementem jednoczącym wszystkie systemy totalitarne jest idea radykalnej autonomii - negacja transcendencji oraz obietnica stworzenia nowego człowieka

28 Por. R. Zimmermann, Philosophie nach Auschwitz. Eine Neubestimmung von Moral in Politik und Gesellschaft, Reinbek bei Hamburg 2005; R. Zimmermann, Moral als Macht. Eine Philosophie der historischen Erfahrung, Reinbek bei Hamburg 2008.

${ }^{29}$ Konieczność dalszych pogłębionych badań nad istotą nazizmu stała się bardzo aktualna po wielu komentarzach, formułowanych na całym świecie po wystąpieniu papieża Josepha Ratzingera w obozie koncentracyjnym Auschwitz-Birkenau 28 maja 2006 roku. „Jestem tu - mówił Benedykt XVI - jako syn narodu niemieckiego - syn tego narodu, nad którym grupa zbrodniarzy zdobyła władzę przez zwodnicze obietnice wielkości, przywrócenia honoru i znaczenia narodowi, roztaczając perspektywy dobrobytu, ale też stosując terror i zastraszenie, by posłużyć się narodem jako narzędziem swojej żądzy zniszczenia i panowania” (Benedykt XVI, Przybyć tu musiałem. Przemówienie wygłoszone 28 maja 2006 roku w byłym niemieckim obozie koncentracyjnym Auschwitz-Birkenau, „L'Osservatore Romano” 284 [2006] 6-7, s. 39). Słowa papieża, ostro krytykowane przez wielu komentatorów, otworzyły na nowo dyskusję dotyczącą rzeczywistych okoliczności powstania systemu narodowosocjalistycznego w kraju nad Renem oraz odpowiedzialności narodu niemieckiego za zbrodnie II wojny światowej. 
i zbawienia w wersji świeckiej. Guardini podkreśla, że postulat autonomicznej wizji bytu ludzkiego dotyczy przede wszystkim komunizmu i narodowego socjalizmu, natomiast faszyzm stanowi bardziej łagodną formę systemu totalitarnego, ponieważ nie ma w nim swego rodzaju przymusu duchowometafizycznego. Faszyzm odnosi się bardziej do tego, co zewnętrzne i nie jest projektem „religijnym”, lecz politycznym.

Guardini twierdzi, że systemy totalitarne niosą ze sobą destrukcję świadomości indywidualnej, godności osoby i jej sumienia moralnego. Jednostka uprzedmiotowiona przez władzę państwa totalitarnego staje się czystym materiałem działania aparatu państwowego. W ten sposób zanika jednostkowość i niepowtarzalność człowieka, który zostaje ujednolicony. Totalitaryzm jest przejawem kryzysu osoby i jej podmiotowości ${ }^{30}$. Korzenie totalitaryzmu sięgają początków nowożytnego żądania egzystencji autonomicznej. Decydującym krokiem w stronę totalitaryzmu były narodziny nowożytnego państwa prawa. W tej koncepcji państwa żądanie autonomii jest postawione w sposób radykalny, tzn. państwo jest pomyślane jako rzeczywistość, która nie ma nad sobą żadnej innej władzy.

Zdaniem Guardiniego w koncepcji nowożytnego państwa prawa znajduje ucieleśnienie kategoria autonomii absolutnej. Żądanie tego rodzaju autonomii w obszarze polityki może prowadzić do niemoralności, w której państwu wolno czynić wszystko, co realizuje jego cele. Przykładem ekstremalnym takiej sytuacji są totalitarne organizmy państwowe, zbudowane na gruncie ideologii komunistycznej i narodowosocjalistycznej ${ }^{31}$. Dramat systemów totalitarnych XX wieku pokazuje bardzo wyraźnie, że koncepcja człowieka całkowicie autonomicznego oraz obietnice zbawienia w wersji immanentnej, nowej moralności i raju na ziemi są fałszem egzystencjalnym, który może prowadzić do masowych zbrodni i tragedii milionów niewinnych ludzi ${ }^{32}$.

30 Por. R. Guardini, Ethik. Vorlesungen an der Universität München (1950-1962), t. 1-2, Mainz-Padeborn 1993, s. 209.

31 Por. R. Guardini, Ethik..., dz. cyt., s. 326.

32 Por. E. Gentile, Contro Cesare. Cristianesimo e totalitarismo nell'epoca dei fascismi, Milano 2016. 


\section{Podsumowanie}

Dwudziestowieczne systemy totalitarne wymagają dzisiaj szeroko zakrojonych badań interdyscyplinarnych. Z jednej strony wiemy coraz więcej o dramatycznych skutkach ich zbrodniczych metod sprawowania władzy w wielu krajach, z drugiej - ciągle brakuje pogłębionych analiz dotyczących filozoficznych korzeni komunizmu, faszyzmu i narodowego socjalizmu. Niestety, tego rodzaju badania naukowe także w naszym kraju nie są prowadzone obecnie na szerszą skalę. Na polskich uniwersytetach prawie w ogóle nie istnieją katedry czy interdyscyplinarne centra badawcze, które zajmowałyby się tą problematyką.

W konsekwencji nie powinien dziwić fakt, że na X Polskim Zjeździe Filozoficznym w Poznaniu we wrześniu 2015 roku, wśród prawie tysiąca wygłoszonych referatów w ogóle nie została podjęta jakże aktualna problematyka natury systemów totalitarnych, ich wewnętrznego zła oraz popełnionych zbrodni. Niestety, w debacie publicznej w Polsce ciągle można spotkać wypowiedzi, w których niemiecki narodowy socjalizm - z powodu wieloletniej propagandy komunistycznej - nazywa się błędnie faszyzmem. To wyraźnie pokazuje, jak wiele jest jeszcze w tej dziedzinie do zrobienia.

O niewyobrażalnym dramacie ubiegłego wieku pisał m.in. włoski filozof Luigi Pareyson (1919-1991), który wypracował koncepcję myślenia tragicznego i odnosił ją w sposób szczególny do ogromu zła spowodowanego w XX wieku przez systemy totalitarne. Pareyson mówił wręcz o kapitulacji prawie całej filozofii w obliczu zła ubiegłego stulecia. Kilka lat przed śmiercią stwierdził, iż zadziwia go fakt, że prawie cała filozofia nie podejmuje tego wyzwania. Warto w tym miejscu dodać, że w ubiegłym stuleciu jednym z największych sowietologów był polski filozof Józef Maria Bocheński (1902-1995), którego badania dotyczące komunizmu powinny być dzisiaj kontynuowane także w naszym kraju.

W tym kontekście należy szczególnie dowartościować opracowania takich autorów, jak Alain Besançon, Augusto Del Noce czy Rolf Zimmermann, którzy walnie przyczynili się do głębszego uchwycenia natury systemów totalitarnych. W dziełach tych myślicieli jest zawarte 
wspólne przekonanie, że mit samozbawienia człowieka i projekt raju na ziemi stanowią najgłębszą przyczynę zła i zbrodni XX wieku. W analizach Besançona wielką rolę odgrywa wykazanie zbrodniczego charakteru komunizmu oraz podkreślenie konieczności równego traktowania zła spowodowanego przez reżimy totalitarne. W badaniach Del Nocego za niezwykle cenne należy uznać połączenie powstania systemów totalitarnych z ideą nowoczesności i procesem sekularyzacji. Natomiast w opracowaniach Zimmermanna ważną rolę odgrywa kategoria moralności zbawienia, która służyła usprawiedliwianiu zła dokonanego w XX stuleciu.

\section{Bibliografia}

Battisti S., Sfondo filosofico generale: l'Italia nel XX secolo, [w:] La filosofia cristiana nei secoli XIX e XX, t. 3: Correnti moderne del XX secolo, a cura di E. Coreth, W. M. Neidl, G. Pfligersdorffer, Roma 1995, s. 621-626.

Benedykt XVI, Przybyć tu musiałem. Przemówienie wygłoszone 28 maja 2006 roku w bytym niemieckim obozie koncentracyjnym Auschwitz-Birkenau, „L'Osservatore Romano” 284 (2006) 6-7, s. 39-40.

Besançon A., Novecento. Il secolo del male. Nazismo, comunismo, Shoah, traduzione a cura di S. Congia, Roma 2000.

Besançon A., Przekleństwo wieku: o komunizmie, narodowym socjalizmie i jedyności Zagłady, tłum. J. Guze, Warszawa 2000.

Besançon A., Świadek wieku. Wybór publicystyki z pierwszego i drugiego obiegu, t. 1, Warszawa 2006.

Besançon A., Świadek wieku. Wybór publicystyki z pierwszego i drugiego obiegu, t. 2, Warszawa 2006.

Chudy W., Gentile Giovanni, [w:] Powszechna encyklopedia filozofii, red. A. Maryniarczyk, t. 3, Lublin 2002, s. 747-750.

Courtois S., Zbrodnie komunizmu, [w:] Czarna ksiegga komunizmu. Zbrodnie, terror, prześladowania, red. S. Courtois, N. Werth, J.-L. Panné, A. Paczkowski, K. Bartosek, J.-L. Margolin, tłum. K. Wakar, Warszawa 1999, s. 23-49.

Del Noce A., Il suicidio della rivoluzione, Santarcangelo di Romagna 1978.

Del Noce A., L'epoca della secolarizzazione, Torino 1970. 
Del Noce A., Secolarizzazione e crisi della modernità, Napolo 1989.

Gentile E., La via italiana al totalitarismo. Il partito e lo Stato nel regime fascista, Roma 2008.

Gentile E., Contro Cesare. Cristianesimo e totalitarismo nell'epoca dei fascismi, Milano 2016.

Gentile G., Riforma della dialettica hegeliana, Messina 1913.

Gentile G., Teoria generale dello spirito come atto puro, Pisa 1916.

Guardini R., Ethik. Vorlesungen an der Universität München (1950-1962), t. 1-2, MainzPadeborn 1993.

Kobyliński A., Chrześcijaństwo i nowożytność, „Collectanea Theologica” 74 (2004) 1, s. $127-145$.

Mutafian C., Metz Yeghérn. Breve storia del genocidio degli armeni, Milano 2001.

Nolte E., Der Faschismus in seiner Epoche, München 1963.

Panzeri F., Torna l'utopia oscura del dissidente Zinov'ev, „Avvenire” 49 (2016) 1, s. 16.

Possenti V., Dentro il secolo breve, Soveria Mannelli 2009.

Possenti V., Profili del Novecento, Torino 2007.

Trocki L., Ich moralność i nasza, tłum. P. Strębski, Warszawa 2004.

Zimmermann R., Moral als Macht. Eine Philosophie der historischen Erfahrung, Reinbek bei Hamburg 2008.

Zimmermann R., Nationalsozialismus - Bolschewismus - Universalismus. Moralische Transformationen in der Geschichte als Problem der Ethik, [w:] Ideologie und Moral im Nationalsozialismus, bearb. W. Bialas, L. Fritze, Göttingen 2014, s. 369-397.

Zimmermann R., Philosophie nach Auschwitz. Eine Neubestimmung von Moral in Politik und Gesellschaft, Reinbek bei Hamburg 2005.

Zinowiew A., Homo sovieticus, tłum. S. Deja, London 1984. 